\title{
Does the major aluminium-resistance gene in wheat, TaALMT1, also confer tolerance to alkaline soils?
}

\author{
Carolina M. S. Silva • Chunyan Zhang • \\ Gustavo Habermann • Emmanuel Delhaize • \\ Peter R. Ryan (D)
}

Received: 5 October 2017 / Accepted: 21 December 2017 / Published online: 5 January 2018

(C) Springer International Publishing AG, part of Springer Nature 2018

\begin{abstract}
Aim A major limitation to plant growth in acid soils is the prevalence of toxic $\mathrm{Al}^{3+}$. Most genotypic variation for acid soil-tolerance in wheat is linked with the $\mathrm{Al}^{3+}$-activated efflux of malate anions from roots which is controlled by TaALMT1 on chromosome 4DL. Recent studies have also linked TaALMT1 with tolerance to high $\mathrm{pH}$ solutions and alkaline soils. This study tested the hypothesis that an $\mathrm{Al}^{3+}$-resistant allele of TaALMT1 also confers tolerance to alkaline conditions.

Methods The near-isogenic wheat lines, ET8 $\left(\mathrm{Al}^{3+}\right.$-resistant) and $\mathrm{ES} 8\left(\mathrm{Al}^{3+}\right.$-sensitive), have different alleles of the TaALMT1 gene and contrasting resistance to $\mathrm{Al}^{3+}$ toxicity. Growth of these lines was compared in acid and alkaline soils with contrasting mineralogy and in a range of high $\mathrm{pH}$ hydroponic solutions of varying composition.

Results No consistent differences in root or shoot growth were detected between the lines in the alkaline soils or in the high $\mathrm{pH}$ hydroponic treatments. Malate

Responsible Editor: Jian Feng Ma

C. M. S. Silva · C. Zhang · E. Delhaize · P. R. Ryan $(\square)$ CSIRO Agriculture and Food, GPO Box 1700, Canberra, ACT 2601, Australia

e-mail: peter.ryan@csiro.au

C. M. S. Silva · G. Habermann

Botanics department, Sao Paulo State University UNESP, Rio Claro, Brazil

C. Zhang

Chengdu Institute of Biology, Chinese Academy of Sciences,

Chengdu, China
\end{abstract}

efflux was detected from ET8 in acidic solution with $\mathrm{Al}^{3+}$ but no substantial malate efflux was detected at pH 9.0 treatment with added $\mathrm{Na}_{2} \mathrm{SO}_{4}$.

Conclusion The results are inconsistent with the hypothesis that the TaALMT1 gene confers an advantage to wheat on alkaline soils.

Keywords Wheat $\cdot$ Malate $\cdot$ TaALMT1 Aluminum . Resistance $\cdot$ Tolerance $\cdot$ Alkaline $\cdot$ Acidic $\cdot$ Soil $\cdot$ Boron

\section{Introduction}

Crop productivity can be limited by both low and high $\mathrm{pH}$ soils. While acid soils have $\mathrm{pH}<7.0$ and alkaline soils have $\mathrm{pH}>7.0$ yields crop production is generally not affected until $\mathrm{pH}$ is less than 5.0 or greater than 7.5. When $\mathrm{pH}$ is less than 4.5 aluminium is released from the aluminosilicates and other minerals such that trivalent aluminium cations $\left(\mathrm{Al}^{3+}\right)$ become the dominate monomeric $\mathrm{Al}$ species in solution. Micromolar concentrations of $\mathrm{Al}^{3+}$ can rapidly inhibit root growth of wheat (Ryan et al. 1992) and the small root systems have reduced capacity for water and nutrient uptake (Foy 1984; Kochian 1995). Acid soils restrict nutrient uptake in other ways. $\mathrm{Al}^{3+}$ can directly inhibit the transporter absorbing $\mathrm{K}^{+}$and $\mathrm{Ca}^{2+}$ or form insoluble complexes with phosphorus which reduces its availability to plants (Gassmann and Schroeder 1994; Pineros and Tester 1993; Zheng 2010).

Alkaline soils also limit plant growth through nutrient deficiencies and toxicities. Some micronutrients are 
less soluble at high pH (e.g. Fe and Mn) and the availability of other minerals is reduced through the formation of complexes. For instance, high calcium concentrations can reduce phosphate availability and $\mathrm{HCO}_{3}{ }^{-}$ and clay minerals can reduced zinc availability (Adcock et al. 2007). Boron and sodium toxicities can be important constraints in some alkaline soils and $\mathrm{HCO}_{3}{ }^{-} / \mathrm{CO}_{3}{ }^{2}$ ${ }^{-}$-related stresses are also important (Millar et al. 2007).

Many plants have adapted to acidic soils by evolving mechanisms that either exclude $\mathrm{Al}^{3+}$ from the root cells or accumulate and sequester them in the vacuole (Kochian et al. 2015; Ma et al. 2001). A mechanism of $\mathrm{Al}$ exclusion now described in many species relies on the release or efflux of organic anions such as malate and citrate from the root apices (Delhaize et al. 2007; Kochian et al. 2015; Ma et al. 2001; Ryan and Delhaize 2010). These organic anions chelate $\mathrm{Al}^{3+}$ in the apoplast and rhizosphere and reduce its potential to damage the root tissues. Malate and citrate release occurs via membrane-bound transport proteins encoded by members of the aluminium activated malate transporter (ALMT) or the multidrug and toxic compound exudation (MATE) gene families, respectively (Delhaize et al. 2007; Delhaize et al. 2012; Furukawa et al. 2007; Magalhaes et al. 2007; Sasaki et al. 2004). In hexaploid wheat, (Triticum aestivum L.) Al resistance is strongly correlated with malate efflux from the root apices via an anion channel encoded by the TaALMT1 gene on chromosome 4DL (Raman et al. 2005; Sasaki et al. 2004). TaALMT1 expression is constitutively higher in the root apices of Al resistant cultivars compared to Al-sensitive cultivars and $\mathrm{Al}^{3+}$ cations are required to directly activate the TaALMT1 proteins to release malate from root apices. Al-resistant cultivars of wheat have greater TaALMT1 expression levels than sensitive cultivars due to the presence of repeated blocks of sequence in the TaALMT1 promoter (Ryan et al. 2010). To date, the major variants or alleles of this region have been designated as Type I to Type VII but more are likely to exist. These alleles reflect the number and order of repeats most of which can be distinguished with genetic markers (Raman et al. 2008; Sasaki et al. 2006). In general, a greater number of repeats is associated with high TaALMT1 expression, more malate efflux and enhanced Al resistance (Ryan et al. 2010). Most Alsensitive cultivars of wheat have the Type I allele with no repeats in the promoter, low TaALMT1 expression and low malate release. Many Al-resistant cultivars possess the Type $\mathrm{V}$ allele which has three large sequence repeats, higher TaALMT1 expression and greater malate release than sensitive cultivars (Raman et al. 2008). ET8 and ES8 are near-isogenic wheat lines that vary in Al resistance at the TaALMT1 locus. ES8 has the Type I allele for TaALMT1 and ET8 has the Type V allele for TaALMT1.

McDonald et al. (2013) analysed 233 trials over 12 years largely from South Australia and Western Australia to assess the contribution of various traits to the variation in grain yield. The study compiled the cultivars, average yields and rainfall events for those trials but did not include soil characteristics. They also measured aspects of root structure, nutrient efficiency and tolerance to certain abiotic stresses (salinity, high $\mathrm{pH}, \mathrm{Al}$ and $\mathrm{B}$ ) of the 52 cultivars studied and combined this information with their known phenology. Among the root traits assessed, tolerance to salinity (as measured by $\mathrm{Na}+$ exclusion) was more frequently associated with high yields across all trials than any other trait. This was followed by resistance to $\mathrm{Al}$ and then by tolerance to B toxicity. The authors found that cultivars tolerant to high $\mathrm{pH}$ were also more likely to be tolerant of B toxicity and, interestingly, cultivars that were more tolerant of B toxicity were also more likely to be resistant to Al toxicity (McDonald et al. 2013).

A similar retrospective study compared average yields from 208 wheat trials with the allelic variation in the major genes controlling phenology, plant height and $\mathrm{Al}$ resistance (Eagles et al. 2014). These trials were also conducted across southern Australia where top soil $\mathrm{pH}$ ranged from mildly acidic ( $\mathrm{pH} 4.8$ to 5.5$)$ to mildly alkaline (pH 7.0 to 8.5 ). Over all sites and experiments no advantage to yield was detected for the Type $\mathrm{V}$ allele of TaALMT1 (associated with Al resistance) compared to the Type I allele (associated with Al sensitivity) even on mildly acidic soils. This is consistent with previous studies that show that the benefit of TaALMT1 is prominent in soil with $\mathrm{pH}<4.5$ where $\mathrm{Al}^{3+}$ cations are prevalent (Tang et al. 2003, b). Unexpectedly, the Type V allele of TaALMT1 was associated with better yields on mildly alkaline soils, especially in hotter environments, and Eagles et al. (2014) speculated that the resistant allele of TaALMT1 might either be protecting roots from the aluminate anions $\left[\mathrm{Al}(\mathrm{OH})_{4}\right]^{-}$in alkaline subsoils (Brautigan et al. 2012) or enhancing nutrient availability by releasing malate anions. The latter idea assumes that TaALMT1 allows malate efflux in alkaline conditions, as in acidic soils, and that malate protects the roots from $\left[\mathrm{Al}(\mathrm{OH})_{4}\right]^{-}$ or other stresses imposed by high-pH soils. 
At the time Eagles et al. (2014) published their results there was no evidence to support the idea that malate release via TaALMT1 could occur in alkaline conditions. The only function assigned to TaALMT1 at that time was to facilitate the $\mathrm{Al}^{3+}$-dependent release of malate in acidic conditions (Delhaize et al. 1993; Ryan et al. 1995; Sasaki et al. 2004). Yet, soon after its publication, further links between TaALMT1 and high-pH tolerance were raised by Ramesh et al. (2015) who also concluded that ET8 wheat was more tolerant of alkaline conditions than ES8. Ramesh et al. (2015) found that ET8 seedlings grew longer roots and released more malate than ES8 after $20 \mathrm{~h}$ treatments in $\mathrm{pH} 9.0$ solutions. Further experiments, with Xenopus laevis oocytes expressing TaALMT1, demonstrated that malate efflux via TaALMT1 could occur at $\mathrm{pH} 7.5$, in the absence of $\mathrm{Al}^{3+}$, if other anions were present in the bathing media (e.g. malate, citrate, $\mathrm{SO}_{4}{ }^{2-}, \mathrm{Cl}^{-}, \mathrm{NO}_{3}{ }^{-}$ or phosphate) (Ramesh et al. 2015). The authors explained this response by proposing the malate efflux was balanced by proton efflux which decreased the apoplastic pH of ET8 roots and either enhanced cell wall extension or improved nutrient uptake. The efflux of organic anions from roots in alkaline soils can benefit plant growth under some conditions (Strom et al. 2005).

The results of Eagles et al. (2014) and Ramesh et al. (2015) are intriguing but uncertainties remain around the links between TaALMT1 function and high $\mathrm{pH}$ tolerance. Soil characterization in the Eagles et al. (2014) study was minimal and included only basic measurements of $\mathrm{pH}$. The growth studies conducted by Ramesh et al. (2015) were short-term hydroponic experiments and none included soil. The present study used the near-isogenic wheat lines ET8 and ES8 to test the main tenets of this hypothesis with growth experiments in a range of contrasting soils and in hydroponics.

\section{Material and methods}

Plant material

ES8 (Al-sensitive) and ET8 (Al-resistant) are nearisogenic lines that differ in $\mathrm{Al}$ resistance at a single major locus at the TaALMT1 gene on chromosome 4DL (Raman et al. 2005; Sasaki et al. 2004). The background of these lines is largely cv. Egret as described previously (Delhaize et al. 1993). ES8 possesses the Type I allele of TaALMT1 (designated TaALMT1-I) which is associated with low levels of TaALMT1 expression in the root apices and low malate efflux. ET8 possesses the Type V allele of the TaALMT1 (designated TaALMTI-V) which is associated with high levels of TaALMT1 expression in root apices and greater malate efflux. (Ryan et al. 2010; Sasaki et al. 2006).

\section{Soil experiments}

Growth was measured in six contrasting soils (Table 1). The Robertson soil ( $\mathrm{pH}=4.08 ;-34.596444$, 150.605952) was acidic, Al-toxic and highly phosphorus $\mathrm{P}$-fixing. An additional treatment with added $\mathrm{KH}_{2} \mathrm{PO}_{4}$ to raise the Colwell $\mathrm{P}$ of this soil from 70 to $239 \mathrm{mg} \mathrm{kg}^{-1}$ was included. This higher Colwell $\mathrm{P}$ was still P-limiting for wheat in longer-term growth studies (Liao et al. 2008). The Wallaroo soil was an acidic but non-Al toxic soil ( $\mathrm{pH}=5.39 ;-35.170848$, 149.053645). The four alkaline soils were collected from the Eyre Peninsula $(\mathrm{pH}=7.82 ;-33.1424$, 134.6956), Streaky Bay ( $\mathrm{pH}=7.67 ;-32.847505$, 134.386523), Mallala ( $\mathrm{pH}=7.95 ;-34.375834$, 138.458392) and Redhill $(\mathrm{pH}=8.02 ;-33.540905$, 138.195753). Moisture content of the Robertson, Wallaroo, Eyre Peninsula and Streaky Bay soils were adjusted to $80 \%$ field capacity and placed in pots $(20 \mathrm{~cm}$ high $\times 8.5 \mathrm{~cm}$ diameter). The growth experiments were conducted in a growth cabinet (day/night was $22{ }^{\circ} \mathrm{C}$ $/ 18{ }^{\circ} \mathrm{C}$ for $\left.16 \mathrm{~h} / 8 \mathrm{~h}\right)$ or glasshouse $\left(22^{\circ} \mathrm{C} / 18{ }^{\circ} \mathrm{C}\right)$ with natural light over 10 days. The Mallala and Redhill soils had high clay contents and prone to cracking. These soils were mixed with $20 \%$ coarse sand, adjusted to moisture contents of $50 \%$ and $60 \%$ field capacity, respectively, and placed in pots $(19 \mathrm{~cm}$ high and $6.3 \mathrm{~cm}$ diameter). Experiments using these soils were run were for seven days.

\section{Hydroponic experiments}

ET8 and ES8 grain were weighed (usually $45-55 \mathrm{mg}$ ) and imbibed on moist filter paper at $4{ }^{\circ} \mathrm{C}$ for two days and then germinated at room temperature for two days. The seedlings were planted in aerated hydroponic tanks or in various soils. Hydroponics experiments used aerated $20 \mathrm{~L}$ tanks $(50 \mathrm{~cm}$ length $\times 30 \mathrm{~cm}$ width $\times 15 \mathrm{~cm}$ height) placed in growth chambers $(16 \mathrm{~h} / 8 \mathrm{~h}$ day/night at $22 / 18^{\circ} \mathrm{C}$ for) or in a glasshouse with natural light. Two basal hydroponic solutions were used that were 
Table 1 Chemical analysis and fertility parameters of the soil types used in the experiments

\begin{tabular}{|c|c|c|c|c|c|c|c|}
\hline & \multicolumn{7}{|l|}{ Soil types } \\
\hline & $\begin{array}{l}\text { Robertson } \\
\text { (NSW) }\end{array}$ & $\begin{array}{l}\text { Robertson }+\mathrm{P} \\
(\mathrm{NSW})\end{array}$ & $\begin{array}{l}\text { Wallaroo } \\
\text { (NSW) }\end{array}$ & $\begin{array}{l}\text { Streaky Bay } \\
(\mathrm{SA})\end{array}$ & $\begin{array}{l}\text { Eyre Pen. } \\
\text { (SA) }\end{array}$ & $\begin{array}{l}\text { Mallala } \\
(\mathrm{SA})\end{array}$ & $\begin{array}{l}\text { Redhill } \\
\text { (SA) }\end{array}$ \\
\hline $\mathrm{pH}\left(\mathrm{CaCl}_{2}\right)$ & 4.1 & 4.2 & 5.4 & 7.7 & 7.8 & 8.0 & 8.0 \\
\hline $\mathrm{C}(\%)$ & 5.23 & 5.58 & 1.17 & 4.44 & 4.16 & 1.48 & 0.770 \\
\hline $\mathrm{N}(\%)$ & 0.365 & 0.394 & 0.100 & 0.205 & 0.174 & 0.0625 & 0.0495 \\
\hline Extr S (mg/kg) & 27.2 & 20.9 & 16.3 & 10.0 & 17.3 & 43.9 & 67.0 \\
\hline $\mathrm{B}(\mathrm{mg} / \mathrm{kg})$ & 0.921 & 1.030 & 0.244 & 2.98 & 5.71 & 4.24 & 18.4 \\
\hline $\begin{array}{l}\text { Exch Al } \\
\quad(\mathrm{cmol}+/ \mathrm{kg})\end{array}$ & 3.85 & 3.09 & 0.018 & 0.014 & 0.013 & 0.014 & 0.009 \\
\hline $\mathrm{Cu}(\mathrm{mg} / \mathrm{kg})$ & 0.459 & 0.682 & 0.508 & 0.102 & 0.114 & 3.09 & 3.10 \\
\hline $\mathrm{Fe}(\mathrm{mg} / \mathrm{kg})$ & 32.8 & 41.5 & 61.8 & 4.27 & 4.45 & 6.83 & 10.0 \\
\hline $\mathrm{Mn}(\mathrm{mg} / \mathrm{kg})$ & 3.82 & 31.0 & 21.4 & 5.57 & 4.95 & 13.4 & 17.8 \\
\hline $\mathrm{Zn}(\mathrm{mg} / \mathrm{kg})$ & 0.18 & 0.49 & 0.93 & 0.56 & 1.05 & 0.83 & 1.29 \\
\hline $\begin{array}{l}\text { Exch } \mathrm{Ca} \\
\quad(\mathrm{cmol}+/ \mathrm{kg})\end{array}$ & 0.73 & 1.26 & 3.70 & 24.0 & 27.4 & 26.4 & 18.9 \\
\hline Exch K (cmol+/kg) & 0.655 & 1.90 & 0.706 & 1.14 & 2.86 & 1.17 & 1.06 \\
\hline $\begin{array}{l}\text { Exch } \mathrm{Mg} \\
\quad(\mathrm{cmol}+/ \mathrm{kg})\end{array}$ & 0.230 & 0.489 & 0.540 & 2.19 & 3.95 & 8.35 & 5.44 \\
\hline $\begin{array}{l}\text { Exch Na } \\
\quad(\mathrm{cmol}+/ \mathrm{kg})\end{array}$ & 0.087 & 0.121 & 0.085 & 0.164 & 0.945 & 3.081 & 3.298 \\
\hline Extr K (mg/kg) & 673 & 357 & 489 & 213 & 376 & 362 & 856 \\
\hline $\mathrm{Cl}(\mathrm{mg} / \mathrm{kg})$ & 6 & 8 & 10 & 11 & 42 & 197 & 156 \\
\hline Amm-N (mg/kg) & 9.77 & 4.14 & 39.7 & 1.97 & 6.94 & 4.56 & 3.88 \\
\hline Nitrate N (mg/kg) & 9.09 & 158 & 4.6 & 99.2 & 44.2 & 9.91 & 13.1 \\
\hline Colwell P (mg/kg) & 70.6 & 239 & 45.0 & 100 & 59.3 & 12.5 & 23.1 \\
\hline Olsen P (mg/kg) & 13 & 50 & 18 & 22 & 12 & 2 & 7 \\
\hline PBI unadj (mg/kg) & 1067 & 881 & 41.2 & 182 & 210 & 160 & 63 \\
\hline PBIcol (mg/kg) & 1143 & 1094 & 48.9 & 208 & 226 & 163 & 67 \\
\hline
\end{tabular}

modified by altering the $\mathrm{pH}$ and adding additional salts. Hydroponic solution 1 consisted of $500 \mu \mathrm{M} \mathrm{CaCl}{ }_{2}$, $150 \mu \mathrm{M} \mathrm{MgSO}_{4}, 500 \mu \mathrm{M} \mathrm{KNO}_{3}, 2 \mu \mathrm{M}$ FeEDTA, $500 \mu \mathrm{M} \mathrm{NH} \mathrm{NO}_{3}, 10 \mu \mathrm{M} \mathrm{KH_{2 }} \mathrm{PO}_{4}, 11 \mu \mathrm{M} \mathrm{H} \mathrm{BO}_{3}$, $2 \mu \mathrm{M} \mathrm{MnCl}_{2}, 0.35 \mu \mathrm{M} \mathrm{ZnSO}$ and $0.2 \mu \mathrm{M} \mathrm{CuCl}$. Various buffers including 4-(2-hydroxyethyl)-1piperazineethanesulfonic acid (HEPES) or bis-Tris propane (BTP) were added to the basal solution along with a variety of other salts including $\mathrm{Na}_{2} \mathrm{CO}_{3}, \mathrm{NaHCO}_{3}$, $\mathrm{Na}_{2} \mathrm{SO}_{4}$ or $\mathrm{Na}_{2} \mathrm{SO}_{4}$. The $\mathrm{pH}$ of the solutions was adjusted as described in the text.

Hydroponic solution 2 was used previously to score wheat cultivars for tolerance to high $\mathrm{pH}$ (McDonald et al. 2013; Millar et al. 2007). The control solution comprised $0.5 \mathrm{mM} \mathrm{Ca}\left(\mathrm{NO}_{3}\right)_{2}, 15 \mu \mathrm{M} \mathrm{H} \mathrm{H}_{3} \mathrm{BO}_{3}$ and $0.2 \mu \mathrm{M} \mathrm{ZnSO}_{4}(\mathrm{pH}$ 6). The high $\mathrm{pH}$ treatment also included $5 \mathrm{mM} \mathrm{NaHCO}, 1 \mathrm{mM} \mathrm{Na} \mathrm{CO}_{3}$ and $5 \mathrm{mM}$ $\mathrm{CaCO}_{3}$ (pH 9.1). The high $\mathrm{pH}$ solution was aerated with $\mathrm{CO}_{2}$-free air by using a $10 \mathrm{M} \mathrm{KOH}$ trap and treatments were monitored daily for $\mathrm{pH}$. Net root growth was compared in the control and high $\mathrm{pH}$ solutions after 10 days.

\section{Measurements}

In the hydroponic experiments the longest root, total root length or root biomass were measured. At the end of the experiment roots and shoots were excised. Roots were scanned using WinRhizo ${ }^{\mathrm{TM}}$ to estimate total root length and then roots and shoots were dried at $70^{\circ} \mathrm{C}$ for two days and weighed. For harvesting soil-grown plants, the roots were washed out and scanned for total 
root length and then roots and shoots were dried and weighed. Relative root length (relative shoot biomass etc) were calculated as root length (shoot biomass) measured at the treatment $\mathrm{pH}$ relative to the control treatment.

\section{Malate efflux}

Malate efflux was measured from root apices excised from sterile seedlings grown in flasks as described previously (Pereira et al. 2010; Ryan et al. 1995). The high $\mathrm{pH}$ treatment included $10 \mathrm{mM} \mathrm{Na} \mathrm{SO}_{4}$ unbuffered at $\mathrm{pH}$ 9.0. Malate in the solutions was estimated with an enzymatic assay (Delhaize et al. 1993).

Boron tolerance

Root and shoot growth of ES8 and ET8 were measured after growth in $20 \mathrm{~L}$ hydroponic basal solution 1 with various $\mathrm{H}_{3} \mathrm{BO}_{3}$ concentrations. The first experiment measured growth after seven days in $0,2.5$ or $5 \mathrm{mM}$ $\mathrm{H}_{3} \mathrm{BO}_{3}$ (pH 6.0) with 16 seedlings per treatment. The second experiment measured growth after 20 days in 0 or $4 \mathrm{mM} \mathrm{H}_{3} \mathrm{BO}_{3}$ ( $\mathrm{pH}$ 6.0) using 10 to 13 replicate seedlings per treatment. Roots were either scanned for total root length or dried with the shoots at $70^{\circ} \mathrm{C}$ for two days and weighed to measure biomass.

\section{Statistical analysis}

Data from total root length, root and shoot dry weight were subjected to Student's t-test $(P=0.05)$. To test for statistical differences in relative root length (relative shoot biomass etc) between ES8 and ET8 we used an adapted statistical analysis described previously (Zhou et al. 2013).

\section{Results}

Soil experiments

Growth experiments were performed with soils collected from New South Wales and South Australia. Characteristics of these soils are summarized in Table 1. The first experiment compared root growth of ES8 and ET8 in soil collected from Robertson and Wallaroo. The Robertson soil was an acidic ferrosol ( $\mathrm{pH} 4.1)$ with high levels of exchangeable Al while Wallaroo soil (pH 5.4) was low in exchangeable Al. Since Robertson soil also had a high phosphate buffering capacity $(\sim 1000 \mathrm{mg}$ $\mathrm{kg}^{-1}$ ) we included an extra treatment with added phosphorus. After 10 days growth in Robertson soil, with or without added P, total root length of ET8 was two to three-fold greater than ES8 which is consistent with their contrasting resistance to Al toxicity (Fig. 1a). Root biomass did not differ between ET8 and ES8 in Robertson soil (Fig. 1b) which is consistent with previous reports showing that while $\mathrm{Al}$ inhibits root elongation the roots become shorter and thicker (Foy 1984). No differences in shoot biomass were detected between ET8 and ES8 (Fig. 1c) which was also similar to previous short-term experiments. In the non-toxic Wallaroo soil $(\mathrm{pH}$ 5.4) total root growth, biomass and shoot biomass were the same for ET8 and ES8 (Fig. 1). These results demonstrate that root growth of ET8 was greater than ES8 in an acid soil containing toxic concentrations

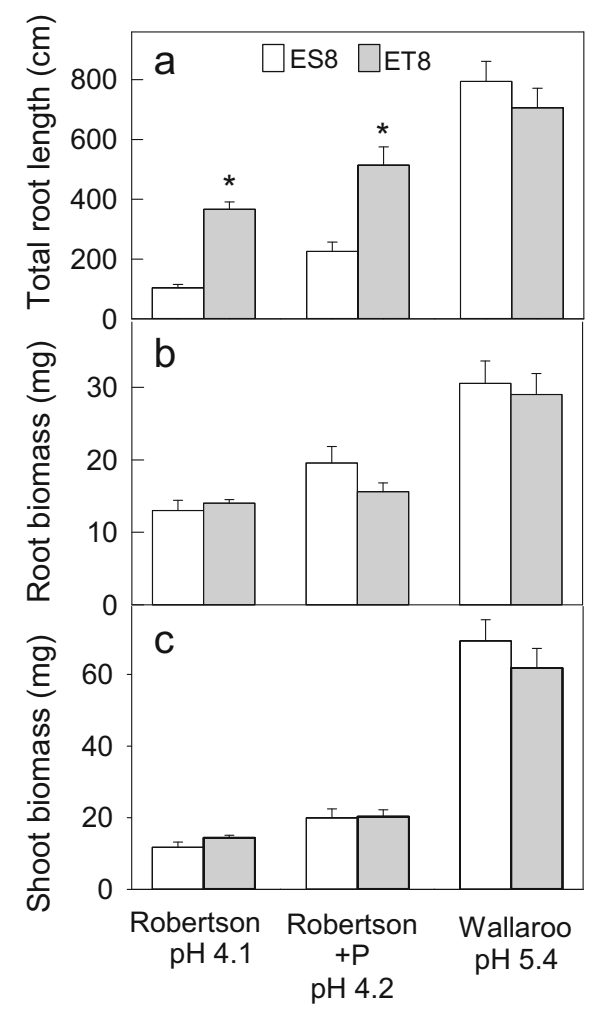

Fig. 1 Root and shoot growth of ET8 and ES8 in acidic soils. Final total root length (a), root biomass (b) and shoot biomass (c) of ET8 and ES8 plants was measured after 10 days growth in the Robertson and Wallaroo soils. Data show the mean and SE $(n=6-$ 8). An asterisk indicates a significant difference between ES8 and ET8 for that soil $(\mathrm{P}<0.05)$ 
of Al. These differences were not observed in a $\mathrm{pH} 5.4$ soil without $\mathrm{Al}$ toxicity.

A series of experiments then compared ES8 and ET8 growth in four contrasting alkaline soils from South Australia with $\mathrm{pH}$ values ranging from 7.7 to 8.0. These experiments measured final total root length, root biomass and shoot biomass. In all four soils no differences were detected between ES8 and ET8 for any parameter (Fig. 2). Trials with the Mallala and Redhill soils were conducted over seven days while those with Streaky Bay or Eyre Peninsular were ten days long.

\section{Hydroponic experiments}

We first confirmed that the batches of ET8 and ES8 grain differed in $\mathrm{Al}$ resistance by growing seedlings for five days in hydroponics with and without $10 \mu \mathrm{M} \mathrm{AlCl}_{3}$

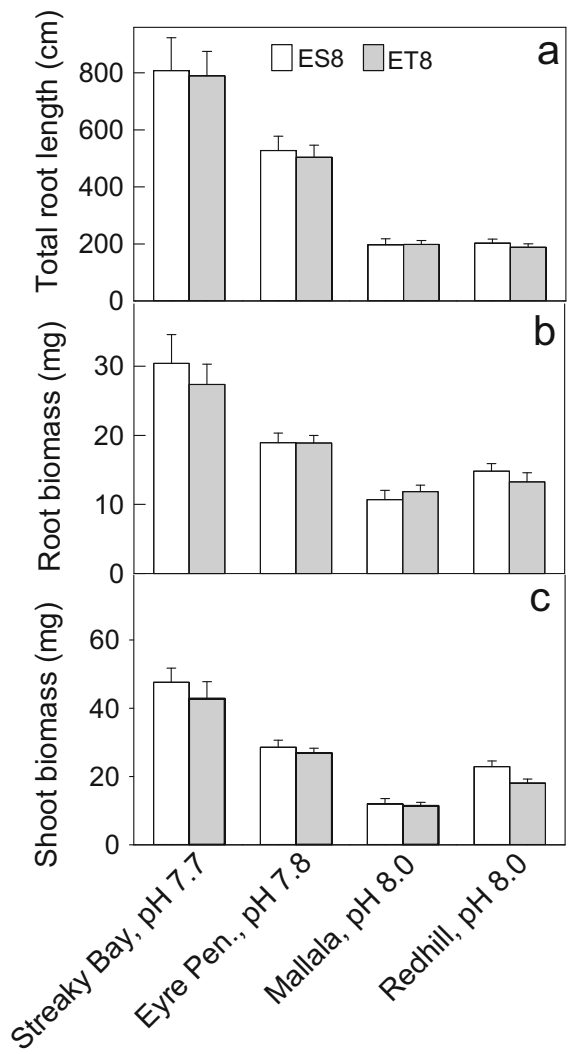

Fig. 2 Root and shoot growth of ET8 and ES8 in alkaline soils. Total root length (a), root biomass (b) and shoot biomass (c) of ET8 and ES8 plants was measured after 10 days growth in the Streaky Bay and Eyre Peninsula soils and after seven days in the Mallala and Redhill soils. Data show the mean and SE $(n=6-8)$. Absence of an asterisk indicates no significant differences between ES8 and ET8 for each soil $(P>0.05)$
(pH 4.3). ET8 and ES8 plants had similar net root growth in the control treatment but, in the presence of Al, root growth of ES8 was significantly inhibited whereas ET8 was unaffected (Fig. 3). Relative root length (RRL) of ET8 was nine-fold greater than ES8.

Growth of ET8 and ES8 was then compared in a series of hydroponic treatments with various added salts and different buffers to adjust $\mathrm{pH}$. These treatments were designed to reflect published reports and mimic conditions in some alkaline soils with high carbonate levels. In some experiments we measured net growth of the longest root while in others we measured total root length (see legends). Also included are calculations of relative root length or relative total root length to account for any variation in seed stocks. Relative values for each genotype are defined as the measurement in a high $\mathrm{pH}$ treatment compared to the value in a control, low $\mathrm{pH}$ treatment.

The first experiment measured root growth in hydroponic solution 1 amended with different anions and buffers. The control solution was $\mathrm{pH} 4.3$ (no Al) while

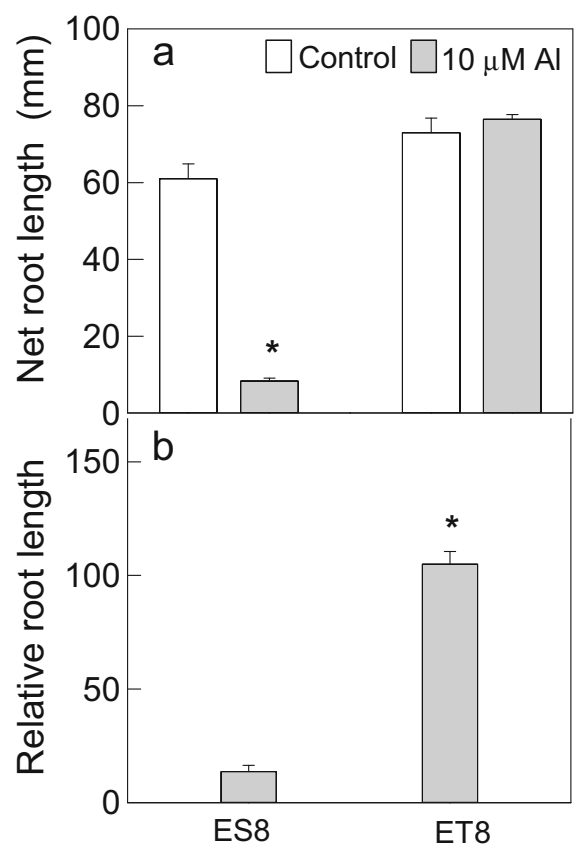

Fig. 3 Comparing the $\mathrm{Al}^{3+}$ resistance of ET8 and ES8 in hydroponics. (a) Net root length (net growth of longest root) and (b) relative root length of ES8 and ET8 after five days growth in hydroponic solution 1 (unbuffered) with and without $10 \mu \mathrm{M} \mathrm{AlCl}_{3}$ (pH 4.3). Data show mean and SE $(n=4)$. Error bars on the data in $\mathrm{b}$ are corrected SE. An asterisk in (a) indicates a significant difference between treatments for each line, whereas an asterisk in (b) indicates a significant difference between ES8 and ET8 using a Students t test $(P<0.05)$ 
the high $\mathrm{pH}$ treatments used $5 \mathrm{mM} \mathrm{NaHCO}$ to adjust $\mathrm{pH}$ to 8.1 or BTP to adjust $\mathrm{pH}$ to 9.5 (Fig. $4 \mathrm{a}, \mathrm{b}$ ). Root growth of ET8 tended to be greater than ES8 in both the $\mathrm{pH} 4.3$ control solution and $\mathrm{pH} 8.1$ solutions but the difference was significantly greater in the $\mathrm{pH} 8.1$ treatment only. However relative root length did not differ between ET8 and ES8.

The second series of experiments used the hydroponic solution $1(\mathrm{pH} \mathrm{6.0)}$ as the control and a series of treatments with added $\mathrm{Na}_{2} \mathrm{CO}_{3}, \mathrm{NaHCO}_{3}$ or $\mathrm{Na}_{2} \mathrm{SO}_{4}$ and buffers, all at pH 8.1 (Figs. 4c,d and 5). Individual treatments did show a significant difference in root growth between ET8 and ES8 for the control, unbuffered, and $2 \mathrm{mM} \mathrm{Na}_{2} \mathrm{SO}_{4}$ treatments but for relative root length the only statistically significant difference was for the $1 \mathrm{mM} \mathrm{Na} \mathrm{CO}_{3}$ treatment where ES8 was greater than ET8.

A third set of hydroponic experiments followed the method used previously to score wheat cultivars for tolerance to high $\mathrm{pH}$ (McDonald et al. 2013; Millar et al. 2007). The control treatment in this experiment was adjusted to $\mathrm{pH} 7.0$ and the high $\mathrm{pH}$ treatment included a mixture of $\mathrm{HCO}_{3}{ }^{-}$and $\mathrm{CO}_{3}{ }^{2-}(\mathrm{pH} 9.1)$ aerated with $\mathrm{CO}_{2}$-free air to miminise $\mathrm{pH}$ changes (McDonald et al. 2013). This experiment was performed twice: one lasting for five days (Fig. 6a,b) and the other for ten days (Fig. 6c-f). Measurements were made of the

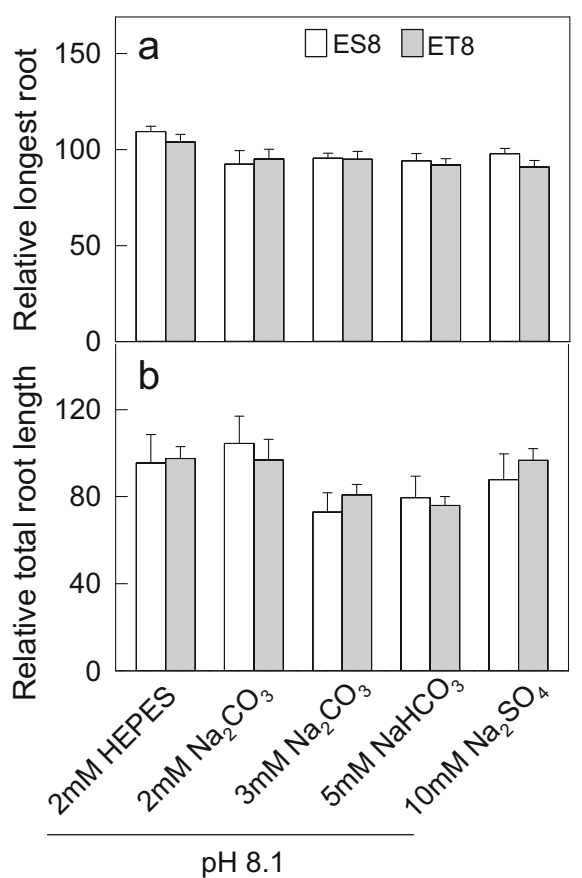

Fig. 5 Root growth of ET8 and ES8 at high pH. Experiment 1 $(\mathrm{a}, \mathrm{b})$ and experiment 2 (c,d) show net growth of the longest root and relative root length of ET8 and ES8 lines after five days growth in hydroponic solution 1 with added treatments as shown. The control treatment was adjusted to $\mathrm{pH}$ 6.0. Data show mean with corrected SE ( $n=5$ to 6 )
Fig. 4 Comparing root growth of ET8 and ES8 in various treatments. Experiment 1 shows net root length (net growth of longest root) in three treatments (a) and relative root length (b) compared to growth in the control (pH 4.3). Experiment 2 shows net root length in six treatments (c) and relative root length (d) compared to the control ( $\mathrm{pH}$ 6.0). Measurements were collected after five days in hydroponic solution 1 amended as shown. Data show mean and SE ( $n=4$ to 6). Error bars on the data in $b$ and $\mathrm{d}$ are corrected SE. An asterisk indicates a significant difference between ES8 and ET8 using a Students t test $(\mathrm{P}<0.05)$
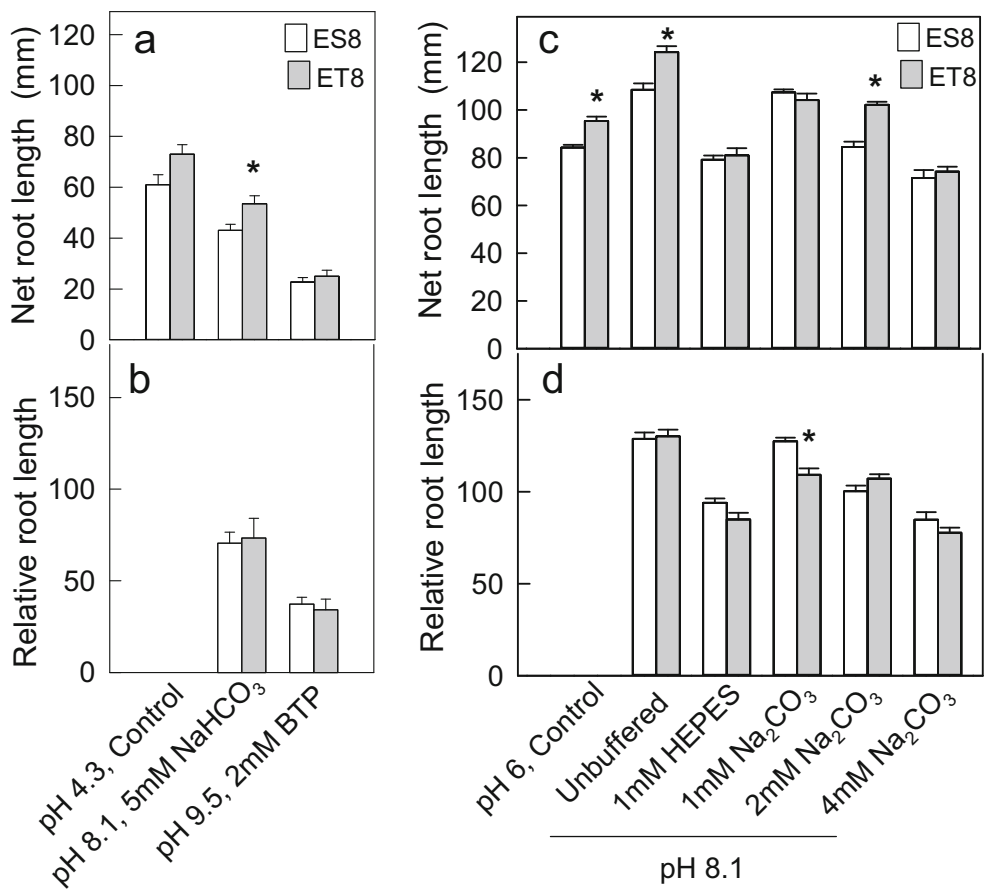


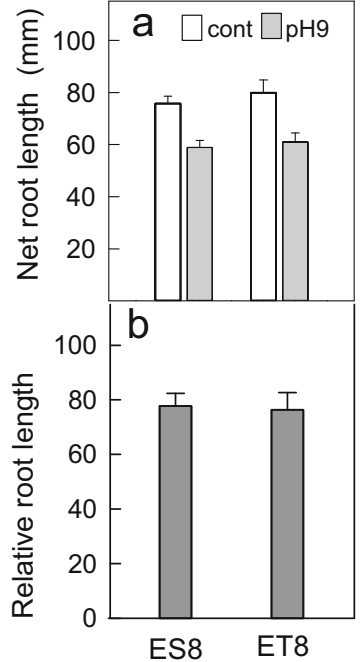

Fig. 6 Root growth of ET8 and ES8 using hydroponic solution 2. Root growth of ET8 and ES8 were compared in hydroponic solution 2 as described by McDonald et al. (2013). Experiment 1 (a, b) compared root length (net growth of longest root) and relative root length after five days. Experiment 2 (c-f) compared root length (c) and total root length (e), as well as relative root

longest root in the first experiment but the second experiment measured the longest root and total root growth. No differences in longest root length or total root length were detected between ET8 and ES8 for either experiment and, correspondingly, no differences in relative growth were detected in these measurements.

\section{Malate efflux at high $\mathrm{pH}$}

Malate release was measured from excised root apices of ET8 and ES8 seedlings. Efflux occurred over one hour in a simple solution $\left(0.2 \mathrm{mM} \mathrm{CaCl}_{2}, \mathrm{pH} 4.5\right)$, with and without addition of $100 \mu \mathrm{M} \mathrm{AlCl}$, or in $0.2 \mathrm{mM}$ $\mathrm{CaCl}_{2}$ and $10 \mathrm{mM} \mathrm{Na}_{2} \mathrm{SO}_{4}$ adjusted to $\mathrm{pH} 9.1$ with $\mathrm{NaOH}$. Malate efflux from ET8 was the same as ES8 for all treatments except for $\mathrm{pH} 4.5$ with $\mathrm{Al}^{3+}$ where efflux from ET8 was four-fold greater than ES8. This is consistent with previous studies comparing Al-resistant and sensitive genotypes of wheat (Delhaize et al. 1993; Ryan et al. 1995) (Fig. 7).

\section{ET8 and ES8 responses to B toxicity}

McDonald et al. (2013) reported that cultivars resistant to $\mathrm{Al}$ toxicity were also more likely to be tolerant to $\mathrm{B}$ toxicity. We tested whether the higher expression of TaALMT1 in ET8 provided any protection from B

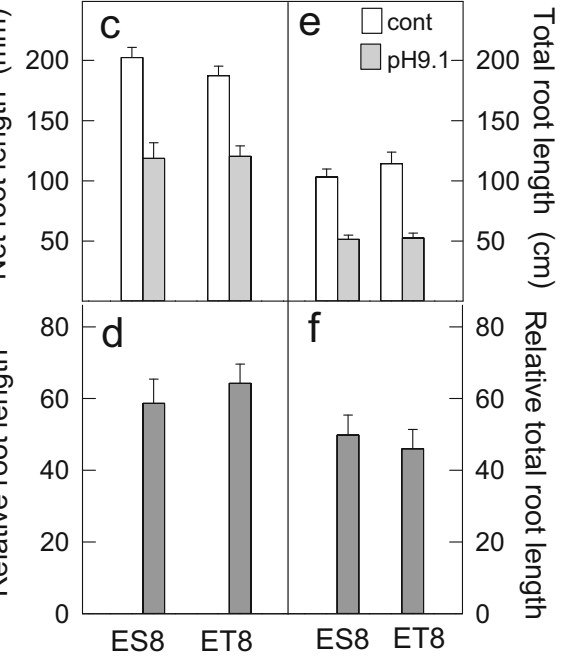

length (d) and relative total root growth (f) after 10 days. The control solution (cont) was adjusted to $\mathrm{pH} 7$ and the high $\mathrm{pH}$ solution was $\sim \mathrm{pH}$ 9.1. Mean and SE $(n=9-10)$ and the absence of asterisks means no significant difference between lines ES8 and ET8 (P 0.05). Error bars on the data in b, $d$ and $f$ are corrected SE

toxicity by measuring root and shoot growth in various $\mathrm{H}_{3} \mathrm{BO}_{3}$ treatments. In the first experiment total root length and final shoot biomass were measured after 12 days in $0,2.5$ and $5.0 \mathrm{mM} \mathrm{H}_{3} \mathrm{BO}_{3}$ (Fig. 8a-d). In a second experiment total root biomass and shoot biomass were measured after 21 days in 0 and $5 \mathrm{mM} \mathrm{H}_{3} \mathrm{BO}_{3}$ (Fig. 8e-h). Growth was significantly inhibited at all B levels with the highest concentration reducing root

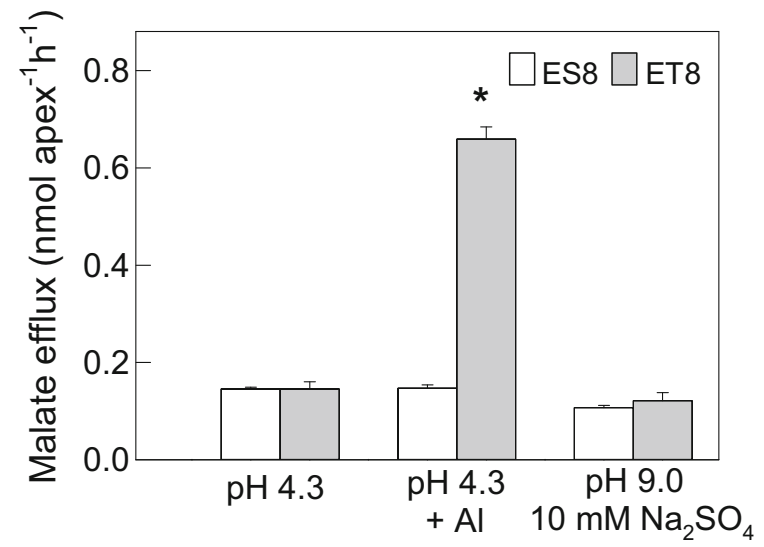

Fig. 7 Malate efflux from the roots of ET8 and ES8. Malate efflux from the excised root apices of ES8 and ET8 seedlings treated with $0.2 \mathrm{mM} \mathrm{CaCl}_{2}$ with and without $100 \mu \mathrm{M} \mathrm{AlCl}_{3}$ (pH 4.3) or $0.2 \mathrm{mM} \mathrm{CaCl}_{2}$ with $10 \mathrm{mM} \mathrm{Na}_{2} \mathrm{SO}_{4}$ (pH 9.0, unbuffered). Data show the mean and $\mathrm{SE}(\mathrm{n}=5)$. The absence of an asterisk indicates no significant differences between ES8 and ET8 $(P>0.05)$ 

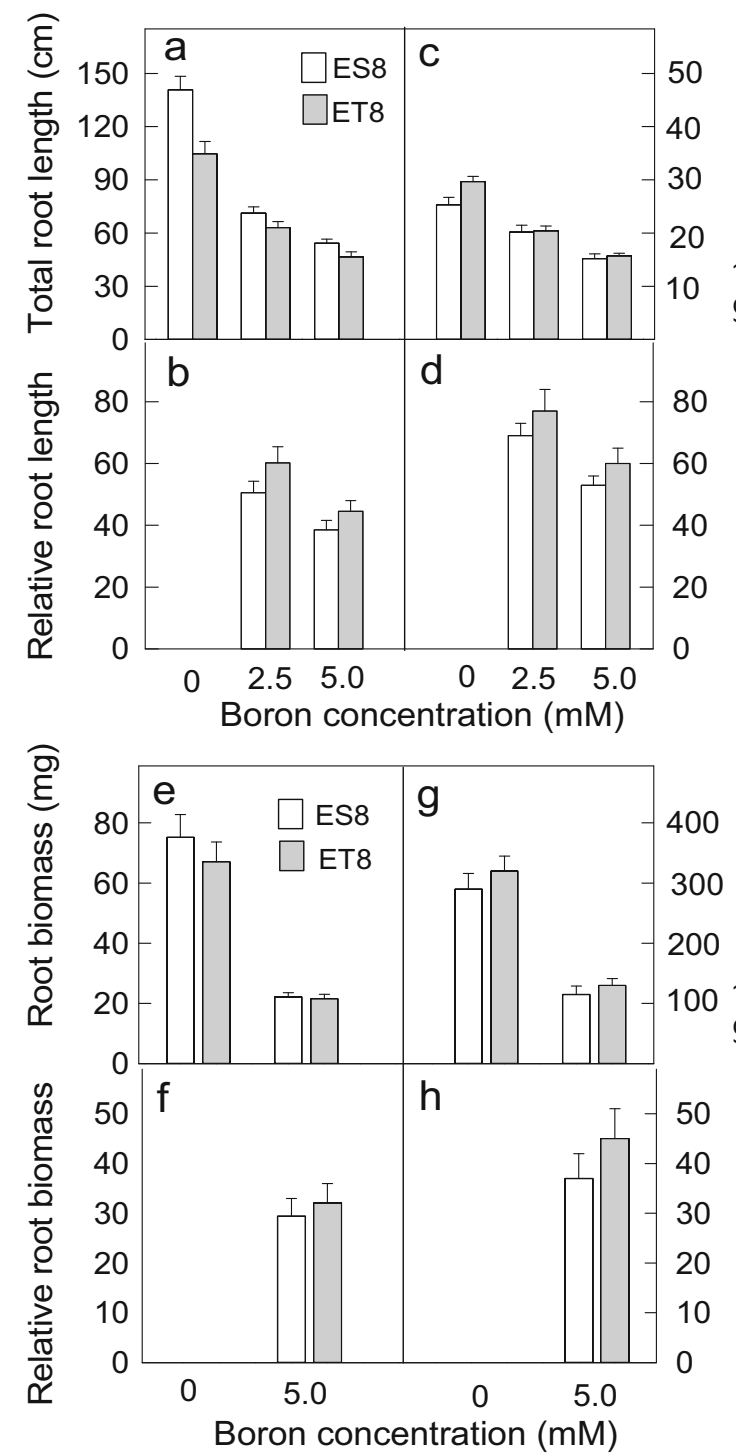

Fig. 8 Comparing the B tolerance of ET8 and ES8. Results from two experiments are shown. Experiment 1 (a-d) shows total root length and shoot biomass after seven days growth in hydroponic solution 1 with $0,2.5$ or $5 \mathrm{mM} \mathrm{H}_{3} \mathrm{BO}_{3}(\mathrm{pH}$ 6.0) Also shown are relative total root growth and relative shoot biomass. Data show the mean and SE $(n=16)$. Experiment $2(\mathbf{e}-\mathbf{h})$ shows root and shoot biomass after 20 days growth in hydroponic solution 1 with 0 or $4 \mathrm{mM} \mathrm{H}_{3} \mathrm{BO}_{3}$. Also shown are relative root and shoot biomass. Data show the mean and SE ( $n=10$ to 13). Error bars on the data in $\mathrm{b}, \mathrm{d}, \mathrm{f}$ and $\mathrm{h}$ are corrected SE. Absence of an asterisk indicates no significant differences between ES8 and ET8 for each hydroponic solution $(\mathrm{P}>0.05)$

growth to $\sim 40 \%$ of controls. No significant differences in total root length, root biomass were detected between ET8 and ES8 in either experiment. Similarly no differences between ES8 and ET8 were detected in shoot biomass in either experiment. The results indicate that in short-term growth assays ET8 and ES8 do not differ in tolerance to B stress.

\section{Discussion}

In a study of 208 wheat trials conducted in South Australia, Victoria and southern NSW Eagles et al. (2014) concluded that wheat with the Type V promoter allele of the TaALMT1 gene (TaALMT1-V) tended to perform better on mildly alkaline soils than wheat with the Type I promoter allele (TaALMT1-I). In other words, cultivars that were tolerant of acid soils tended to yield better on mildly alkaline soils than cultivars that were sensitive to acid soils. The inference was that TaALMT1, the major gene controlling tolerance to acid soils, was protecting plants from one or more of the stresses present in high $\mathrm{pH}$ soils. Prior to that study, the only function assigned to the TaALMT1 anion channel was to facilitate the $\mathrm{Al}^{3+}$-dependent release of malate from roots. Since $\mathrm{Al}^{3+}$ cations occur in acid soils, not alkaline soils, the findings of Eagles et al. (2014) were unexpected. These ideas require TaALMT1 to release malate in high $\mathrm{pH}$ conditions in the absence of free $\mathrm{Al}^{3+}$ ions.

Nevertheless support for the conclusion of Eagles et al. (2014) was provided by Ramesh et al. (2015) who independently concluded that ET8 was more tolerant of alkaline conditions than ES8. Ramesh et al. (2015) compared net root growth in young ES8 and ET8 seedlings over $20 \mathrm{~h}$ in $1.8 \mathrm{ml}$ of $3 \mathrm{mM} \mathrm{CaCl}_{2}$, $5 \mathrm{mM} \mathrm{MES} / \mathrm{BTP}$ and $10 \mathrm{mM} \mathrm{SO}_{4}{ }^{2-}$ (pH 9.0). Additional experiments with seedlings, as well as heterologous expression systems (tobacco suspension cells and Xenopus oocytes), demonstrated that malate efflux via TaALMT1 did indeed occur at $\mathrm{pH}>7.5$ as long as $10 \mathrm{mM}$ concentrations of organic or inorganic anions were added to the external media (Ramesh et al. 2015). They suggested protons released with the malate lowered the apoplastic $\mathrm{pH}$ of the root cells which improved root growth.

However, Eagles et al. (2014) compared wheat varieties, not near-isogenic lines, and Ramesh et al. (2015) did not perform soil trials. The present study tested the main tenets of this hypothesis using the near-isogenic wheat lines ET8 and ES8. We confirmed that our stocks of ET8 and ES8 differed in $\mathrm{Al}^{3+}$ resistance both in acid soil and hydroponic experiments. However the only differences in root growth between ET8 and ES8 in soil 
experiments occurred in the acidic ferrosol that contained high levels of exchangeable Al. No differences in root growth were detected in four other alkaline soils of varying mineralogy. In the hydroponic experiments large differences in root growth between ES8 and ET8 also occurred in an acidic solution with toxic levels of $\mathrm{Al}^{3+}$ but no consistent differences in root growth were detected in any of the treatments with $\mathrm{pH}$ ranging from $\mathrm{pH} 8.0$ to 9.1. These included specific solutions previously used to screen wheat cultivars for tolerance to high $\mathrm{pH}$. Finally, we detected malate efflux from ET8 roots in acidic solution with $\mathrm{Al}^{3+}$ but no substantial malate efflux was detected in another treatment at $\mathrm{pH} 9.1$.

In a different survey of wheat yields over southern Australia McDonald et al. (2013) concluded that cultivars resistant to $\mathrm{Al}$ toxicity were no more likely to be tolerant of high $\mathrm{pH}$. This does not support the model presented by Eagles et al. (2014) but it is consistent with other information. For example Krichauff, one of the most successful wheat cultivars in the highly-alkaline soils of South Australia, has the Type I promoter allele for TaALMT1 and is sensitive to Al toxicity (Millar et al. 2007; Raman et al. 2008). This suggests that TaALMT1 is unlikely to be a major contributor to high $\mathrm{pH}$ tolerance or, at least, is not an important source for breeding purposes.

Eagles et al. (2014) noted that a more comprehensive characterization of the soils would have helped their analysis. This is particularly true for soil $\mathrm{pH}$ which was only defined by general categories in the topsoil (mildly acidic, neutral, mildly alkaline). Eagles et al. (2014) argued that many soils in the "mildly alkaline" category could have been much more alkaline at depth. They proposed that the TaALMT1-V could have been protecting plants from the aluminate anion, $\mathrm{Al}(\mathrm{OH})_{4}{ }^{-}$, which is more prevalent at high $\mathrm{pH}$ and potentially toxic to plants (Brautigan et al. 2012). However no mechanism was provided as to how malate efflux via TaALMT1 could afford protection from aluminate. It could be equally argued that a mildly alkaline topsoil could overlay a more acidic subsoil. The application of lime to correct sub-soil acidity is now becoming routine and since lime can take years to move down the profile, especially in minimal till production systems, it is common for soils to have a much higher $\mathrm{pH}$ in the topsoil than at depth (Dolling et al. 2001; Helyar 1991). Therefore it is possible that, for a subset of the mildly alkaline soils, TaALMT1-V was protecting plants from subsoil acidity. Admittedly, if this was occurring we would have also expected TaALMT1-V to provide a yield advantage in mildly acidic soils for the same reasons, but this was not observed (Eagles et al. 2014).

McDonald et al. (2013) concluded that the genotypic variation in high $\mathrm{pH}$ tolerance was relatively small among the 208 cultivars they tested and that tolerance to high $\mathrm{pH}$ per se was less important than the other sub-soil limitations that occur on alkaline soils such as salinity and B toxicity. Approximately $30 \%$ of cropping soils in South Australia have B concentrations above the recommended levels of $15 \mathrm{mg} / \mathrm{kg}$ soil. Indeed, McDonald et al. (2013) found that that cultivars tolerant of B toxicity were more likely to be tolerant of high $\mathrm{pH}$ and more resistant to $\mathrm{Al}$ toxicity. Whether this association is related by a common physiological function, genetically linked traits or just co-incidental, is unclear.

Tolerance to B toxicity in plants generally depends on excluding B from the roots and shoots. An important mechanism of B tolerance in barley relies on the efflux of borate anions from root cells via an anion channel encoded by HvBOT1 on chromsome 4H (Reid 2007; Sutton et al. 2007). Several QTL for B tolerance in wheat are associated with superior yields in the high-B soils of southern Australia (Jefferies et al. 2000; Nable et al. 1997; Paull et al. 1991). Two of these QTL on chromosomes 7BL (Bol) and 4AL (Bo4) contain genes that encode anion channels similar to HvBOT1 and presumably function in the same way - even though they are not direct orthologues of the barley gene (Pallotta et al. 2014).

Interestingly, a link between ALMT transporters and $\mathrm{B}$ tolerance was reported recently in rice. Overexpression of the rice OSALMT4 gene slightly enhanced the B tolerance of the transgenic lines (Liu et al. 2017) and the authors proposed that OsALMT4 might be facilitating the efflux of borate anions in a similar manner as the BOT1-like proteins in barley and wheat. Those findings together with the study of McDonald et al. (2013) prompted us to directly compare the B tolerance of ET8 and ES8 to determine whether different alleles of TaALMT1 could explain the observation of Eagles et al. (2014). Fortunately, the genetic background of these near-isogenic is largely from the cultivar Egret which is sensitive to B (Jefferies et al. 2000) and convenient for assessing the effect of TaALMT1-V. We found no significant differences in root or shoot biomass between ET8 and ES8 grown in toxic concentrations of 
B. This indicates that TaALMT1 does not substantially contribute to B tolerance, at least in these short-term growth assays.

\section{Conclusions}

We performed a series of short-term growth trials to test the conclusions of Eagles et al. (2014) and Ramesh et al. (2015) that the Al resistance gene TaALMT1 also improves growth and performance at high $\mathrm{pH}$. We found no consistent evidence that ET8 or ES8 differed in their tolerance to alkaline soils, high $\mathrm{pH}$ solutions or to $\mathrm{B}$ toxicity. We could not corroborate previous reports that malate efflux occurs via TaALMT1 under alkaline conditions and so the effect of malate efflux on root growth in alkaline soils requires further investigation. Future work should test these findings with near-isogenic lines in full-season field trials on a range of alkaline soils.

Acknowledgements The authors are grateful to Glenn McDonald, Rhiannon Schilling, Ian Richter and Naomi Scholz for providing alkaline soils from South Australia. We thank Kumara Weligama for assistance in characterizing the soils. Carolina Silva's research was supported by the São Paulo Research Foundation (Fapesp) in Brazil.

\section{References}

Adcock D, McNeill AM, McDonald GK, Armstrong RD (2007) Subsoil constraints to crop production on neutral and alkaline soils in south-eastern Australia: a review of current knowledge and management strategies. Aust J Exp Agric 47:12451261. https://doi.org/10.1071/ea06250

Brautigan D, Rengasamy P, Chittleborough D (2012) Aluminium speciation and phytotoxicity in alkaline soils. Plant Soil 360: 187-196

Delhaize E, Craig S, Beaton CD, Bennet RJ, Jagadish VC, Randall PJ (1993) Aluminum tolerance in wheat (Triticum aestivum L.). 1. Uptake and distribution of aluminum in root apices. Plant Physiol 103:685-693

Delhaize E, Gruber BD, Ryan PR (2007) The roles of organic anion permeases in aluminium resistance and mineral nutrition. FEBS Lett 581:2255-2262. https://doi.org/10.1016/j. febslet.2007.03.057

Delhaize E, Ma JF, Ryan PR (2012) Transcriptional regulation of aluminium tolerance genes. Trends Plant Sci 17:341-348. https://doi.org/10.1016/j.tplants.2012.02.008

Delhaize E, Ryan PR, Randall PJ (1993) Aluminum tolerance in wheat (Triticum aestivum L.). 2. Aluminum-stimulated excretion of malic acid from root apices. Plant Physiol 103: 695-702
Dolling P, Moody P, Noble I, Helyar K, Hughes B, Reuter D, Sparrow L (2001) Soil acidity and acidification in Australia. National Land and Water Resources Audit Project Report, Canberra

Eagles HA, Cane K, Trevaskis B, Vallance N, Eastwood RF, Gororo NN, Kuchel H, Martin PJ (2014) Ppd1, Vrn1, $A L M T 1$ and $R h t$ genes and their effect on grain yield in lower rainfall environments in southern Australia. Crop Pasture Sci 65:159-170

Foy CD (1984) Physiological effects of hydrogen, aluminum, and manganese toxicities in acid soil. In: Adams F (ed) Soil acidity and liming. American Society of Agronomy, Crop Science Society, American Society of Soil Science, Madison

Furukawa J, Yamaji N, Wang H, Mitani N, Murata Y, Sato K, Katsuhara M, Takeda K, Ma JF (2007) An aluminumactivated citrate transporter in barley. Plant Cell Physiol 48: 1081-1091. https://doi.org/10.1093/pcp/pcm091

Gassmann W, Schroeder JI (1994) Inwardly-rectifying K ${ }^{+}$channels in roots hairs of wheat - a mechanism for aluminumsensitive low-affinity $\mathrm{K}^{+}$uptake amd membrane potential control. Plant Physiol 105:1399-1408

Helyar KR (1991) The management of acid soils. In: Wright RJ (ed) Plant-soil interactions at low pH. p 365-382. Kluwer Academic, Dordrecht

Jefferies SP, Pallotta MA, Paull JG, Karakousis A, Kretschmer JM, Manning S, Islam A, Langridge P, Chalmers KJ (2000) Mapping and validation of chromosome regions conferring boron toxicity tolerance in wheat (Triticum aestivum). Theor Appl Genet 101:767-777

Kochian LV (1995) Cellular mechanisms of aluminum toxicity and resistance in plants. Annu Rev Plant Physiol Plant Mol Biol 46:237-260

Kochian LV, Pineros MA, Liu J, Magalhaes JV (2015) Plant Adaptation to Acid Soils: The Molecular Basis for Crop Aluminum Resistance. Annu Rev Plant Biol 66:571-598. https://doi.org/10.1146/annurev-arplant-043014-114822

Liao M, Hocking PJ, Dong B, Delhaize E, Richardson AE, Ryan PR (2008) Variation in early phosphorus-uptake efficiency among wheat genotypes grown on two contrasting Australian soils. Aust J Agric Res 59:157-166. https://doi.org/10.1071 /ar06311

Liu J, Xu M, Estavillo G, Delhaize E, White RM, Zhou M, Ryan PR (2017) OsALMT4 encodes a malate-permeable anion channel in rice (Oryza sativa L.) which is expressed widely and required for normal growth in low light. Plant Physiol (submitted)

Ma JF, Ryan PR, Delhaize E (2001) Aluminium tolerance in plants and the complexing role of organic acids. Trends Plant Sci 6: 273-278

Magalhaes JV, Liu J, Guimaraes CT, Lana UGP, Alves VMC, Wang YH, Schaffert RE, Hoekenga OA, Pineros MA, Shaff JE, Klein PE, Carneiro NP, Coelho CM, Trick HN, Kochian LV (2007) A gene in the multidrug and toxic compound extrusion (MATE) family confers aluminum tolerance in sorghum. Nat Genet 39:1156-1161. https://doi.org/10.1038 /ng2074

McDonald GK, Taylor JD, Verbyla A, Kuchel H (2013) Assessing the importance of subsoil constraints to yield of wheat and its implication for yield improvement. Crop Pasture Sci 63: 1043-1065 
Millar AL, Rathjen AJ, Cooper DS (2007) Genetic variation for subsoil toxicities in high $\mathrm{pH}$ soils. In: Buck HT, Nisi JE, Salomon N (eds) Wheat production in stressed environments. Springer, Dordrecht

Nable RO, Banuelos GS, Paull JG (1997) Boron toxicity. Plant Soil 193:181-198

Pallotta M, Schnurbusch T, Hayes J, Hay A, Baumann U, Paull J, Langridge P, Sutton T (2014) Molecular basis of adaptation to high soil boron in wheat landraces and elite cultivars. Nature 514:88. https://doi.org/10.1038/nature13538

Paull JG, Rathjen AJ, Cartwright B (1991) Major gene control of tolerance of bread wheat (Triticum aestivum L.) to high concentrations of soil boron. Euphytica 55:217-228

Pereira JF, Zhou G, Delhaize E, Richardson T, Ryan PR (2010) Engineering greater aluminium resistance in wheat by overexpressing TaALMT1. J Exp Bot 106:205-214

Pineros M, Tester M (1993) Plasma-membrane $\mathrm{Ca}^{2+}$ channels in roots of higher roots and their role in aluminum toxicity. Plant Soil 156:119-122

Raman H, Ryan PR, Raman R, Stodart BJ, Zhang K, Martin P, Wood R, Sasaki T, Yamamoto Y, Mackay M, Hebb DM, Delhaize E (2008) Analysis of TaALMT1 traces the transmission of aluminum resistance in cultivated common wheat (Triticum aestivum L.) Theor Appl Genet 116:343-354. https://doi.org/10.1007/s00122-007-0672-4

Raman H, Zhang KR, Cakir M, Appels R, Garvin DF, Maron LG, Kochian LV, Moroni JS, Raman R, Imtiaz M, DrakeBrockman F, Waters I, Martin P, Sasaki T, Yamamoto Y, Matsumoto H, Hebb DM, Delhaize E, Ryan PR (2005) Molecular characterization and mapping of ALMT1, the aluminium-tolerance gene of bread wheat (Triticum aestivum L.) Genome 48:781-791

Ramesh SA, Tyerman SD, Xu B, Bose J, Kaur S, Conn V, Domingos P, Ullah S, Wege S, Shabala S, Feijo JA, Ryan PR, Gilliham M (2015) GABA signalling modulates plant growth by directly regulating the activity of plant-specific anion transporters. Nat Commun 6. doi: https://doi. org/10.1038/ncomms 8879

Reid RJ (2007) Identification of boron transporter genes likely to be responsible for tolerance to boron toxicity in wheat and barley. Plant Cell Physiol 48:1673-1678

Ryan PR, Delhaize E (2010) The convergent evolution of aluminium resistance in plants exploits a convenient currency. Funct Plant Biol 37:275-284. https://doi.org/10.1071/fp09261
Ryan PR, Delhaize E, Randall PJ (1995) Characterization of Alstimulated efflux of malate from the apices of Al-tolerant wheat roots. Planta 196:103-110

Ryan PR, Raman H, Gupta S, Sasaki T, Yamamoto Y, Delhaize E (2010) The multiple origins of aluminium resistance in hexaploid wheat include Aegilops tauschii and more recent cis mutations to TaALMT1. Plant J 64:446-455. https://doi. org/10.1111/j.1365-313X.2010.04338.x

Ryan PR, Shaff JE, Kochian LV (1992) Aluminum toxicity in roots: Correlation between ionic currents, ion fluxes and root elongation in Al-tolerant and Al-sensitive wheat cultivars. Plant Physiol 99:1193-1200

Sasaki T, Ryan PR, Delhaize E, Hebb DM, Ogihara Y, Kawaura K, Noda K, Kojima T, Toyoda A, Matsumoto H, Yamamoto Y (2006) Sequence upstream of the wheat (Triticum aestivum L.) ALMT1 gene and its relationship to aluminum resistance. Plant Cell Physiol 47:1343-1354. https://doi.org/10.1093 /pcp/pcl002

Sasaki T, Yamamoto Y, Ezaki B, Katsuhara M, Ahn SJ, Ryan PR, Delhaize E, Matsumoto H (2004) A wheat gene encoding an aluminum-activated malate transporter. Plant J 37:645-653. https://doi.org/10.1111/j.1365-313X.2003.01991.x

Strom L, Owen AG, Godbold DL, Jones DL (2005) Organic acid behaviour in a calcareous soil implications for rhizosphere nutrient cycling. Soil Biol Biochem 37:2046-2054. https://doi.org/10.1016/j.soilbio.2005.03.009

Sutton T, Baumann U, Hayes J, Collins NC, Shi BJ, Schnurbusch T, Hay A, Mayo G, Pallotta M, Tester M, Langridge P (2007) Boron-toxicity tolerance in barley arising from efflux transporter amplification. Science 318:1446-1449. https://doi. org/10.1126/science. 1146853

Tang C, Nuruzzaman M, Rengel Z (2003) Screening wheat genotypes for tolerance of soil acidity. Aust J Agric Res 54:445452. https://doi.org/10.1071/ar02116

Tang C, Rengel Z, Diatloff E, Gazey C (2003) Responses of wheat and barley to liming on a sandy soil with subsoil acidity. Field Crop Res 80:235-244. https://doi.org/10.1016/s0378-4290 (02)00192-2

Zheng SJ (2010) Crop production on acidic soils: overcoming aluminium toxicity and phosphorus deficiency. Ann Bot 106:183-184

Zhou GF, Delhaize E, Zhou MX, Ryan PR (2013) The barley MATE gene, HvAACT1, increases citrate efflux and $\mathrm{Al}^{3+}$ tolerance when expressed in wheat and barley. Ann Bot 112:603-612. https://doi.org/10.1093/aob/mct135 